\title{
Gendered Cinematic Landscapes and Production History of AndreI Davies's Jane Austen From Pride and Prejudice to Sense and Sensibility
}

\author{
Sheri Chinen Biesen \\ Rowan University
}

\begin{abstract}
This article investigates British writer Andrew Davies' media adaptations of Jane Austen from BBC's Pride and Prejudice (1995) to Sense ar Sensibility (2008) and examines how their gendered cinematic landscapes, sexual polemics, location shooting, and production history reframe femini concerns, societal and class constraints, and complex issues of masculinity and gender bending sexual identity. These gendered considerations are embodied in the moody landscapes affected by the filming on location of Davies' cinematic incarnation of Austen's work on screen. With wit and insight, Davies adapts and reimagines the romantic Regency England world of Jane Austen with turbulent landscapes on screen to explore and comment on provocative issues of gender, masculinity, sexuality, money, power, economic survival, turbulent emotional struggle smoldering beneath the surface of a repressed society of gender norms.
\end{abstract}

We sometimes go on as though people can't express themselves. In fact they're always expressing themselves...it's not a problem of getting people express themselves but of providing little gaps of solitude and silence in which they might eventually find something to say. Repressive forces don't stop people expressing themselves but rather force them to express themselves; What a relief to have nothing to say, the right to say nothing, because only then is there a chance of framing the rare, and ever rarer, thing that might be worth saying. - Gilles Deleuze, Negotiations, 1972-1990["

Deleuze's insightful observation on human interaction and communication, or lack thereof, could easily be a description of Jane Austen's Pride and Prejudice and Sense and Sensibility, capturing the spirit of expression or repressed inner turmoil. In honor of the bicentennial of Jane Austen, I will examine the gendered cinematic landscapes, sexual polemics and production history of British writer Andrew Davies's media adaptations of Jane Austen from BBC's Pride and Prejudice (1995) to Sense and Sensibility (2008). ${ }^{[2]}$ Cinematic landscapes filmed on location are central to Davies's me rendering of Austen's romance stories. Moreover, Davies is a key figure in adapting and projecting Austen against these landscapes in his cinematic romance narratives on screen. Yet, despite extensive scholarship on Austen, and Davies's significant role in adapting Austen to screen, little scholarl attention has been given to Davies's contributions to portraying Austen against gendered media landscapes in his narratives and their relation to the production history context of their filming. ${ }^{[3]}$ Davies's rendering of Austen insightfully frames gender, societal and class constraints, and sexual ident of women, which not only highlights feminist concerns and targets women, but also transcends this gendered demographic to reveal complex issue of masculinity and gender bending sexual identity. These gendered considerations are embodied in the moody landscapes affected by the filming of Davies's cinematic incarnation of Austen's work on screen. ${ }^{[4]}$

With wit and insight, Davies adapts and reimagines the romantic Regency England world of Jane Austen with turbulent landscapes on screen to explore and comment on provocative issues of gender, masculinity, sexuality, money, power, economic survival, turbulent emotional struggle smoldering beneath the surface of a repressed society of gender norms and acceptable manners, and young heroines discovering love and sexualit and often betrayal, for the first time after faced with the reality of finding a romantic beau to marry and being dependent on men in order to live or bf thrown out of their family home. ${ }^{[5]}$ Significantly, Davies's version of Austen's story also features images of an anxious Darcy gazing out the window thinking of and writing to Elizabeth to further develop and humanize his character and subjectively identify with his brooding masculine sexual identi [6]

Davies's screen adaptations of Austen, and their projections of gender and masculinity, raise fascinating issues of gendered authorship in his adapti work written by women which is then produced or directed, and thus cinematically mediated, by women. These authorial productions of gender inscribe Davies's adaptations and their screen narratives of Austen mediated by Davies, then produced and refracted by women creative talent (e.g. Anne Pivcevic, Sue Birtwistle, et. al.). ${ }^{[7]}$ They also create a romantic screen climate for gender bending identity.

"I wish I was a man," precocious young Margaret Dashwood (Lucy Boynton) says to her mother (Janet McTeer) in a moment of frustration near the $\epsilon$ of Davies's 2008 BBC adaptation of Austen's 1811 novel Sense and Sensibility. Against the beautiful, rugged backdrop of grassy hills on the Devon coast, Margaret reveals remarkable insight and perception beyond her years as she laments: "Girls can never do anything. Men can ride about the country and do things. And girls just sit and wait for things to happen." ${ }^{[8]}$ Describing the gender constraints of Austen's Regency England era in the early 1800 s, she also expresses regret that she is a sister rather than a brother who can fight the scoundrel who broke her sister's heart and kill him with her sword. In an exchange that begins in innocuous humor between a mother and her daughter sitting in the garden outside their cottage, a serious transformation takes place to provide a profound declaration on gender injustice at an historical moment in time. After joking with her daugh about not wanting to see her hanged for committing murder, Mrs. Dashwood has nothing to say and is silent, reflecting upon Margaret's statement appraising the gender binary of men and women. The scene opens with a shot of the ocean surf crashing against jagged rocks on the shore and is followed by images of the tide flowing against the cold grey stones, which visually illustrates the frustrating emotions of the characters. This momen 
becomes a self-reflexive commentary in Davies's adaptation of Austen's Sense and Sensibility which develops supporting characters to cut to the heart of recurrent thematic motifs about gender and power during the Regency England era in Davies's rendering of Austen's work. This exchange ir Sense and Sensibility is a wonderful example of how Davies's adaptations bring such central issues in Austen's novels cinematically to life on screer

Davies has been praised for his acclaimed 1995 BBC adaptation of Austen's 1813 novel Pride and Prejudice, which made Colin Firth a huge star wh his arrogant character Mr. Darcy plunges into a lake and emerges in a clinging wet shirt to greet romantic heroine Elizabeth Bennett (Jennifer Ehle). I fact, Davies is known for his witty incarnations of Austen, 'his favorite author,' on screen, and is especially 'associated' with cinematically and televisually adapting the 'wit, humor and tight plotting' of Austen's novels..$^{[9]}$ In particular, Davies has been recognized for emphasizing the recurrent themes and dilemmas centering on issues of sex and money in Austen's critique of gender constraints in her work anticipating feminist commentary Ironically, Davies has achieved tremendous success in adapting these themes in screen versions of Austen's novels by developing under-recognizec or supporting characters and scenes, such as more fully developing the male characters and masculine point of view in addition to the subjective perspective of the women in Austen's stories. In fleshing out these characters, Davies creates depth in his renderings of adapting Austen's work in transposing it to cinematic and televisual screens to convey issues of gender polemics, masculinity, power, and sexual identity in romance.

Moreover, in Pride and Prejudice and Sense and Sensibility the cinematic iconography of gendered landscapes beautifully and powerfully conveys Davies's portrayal of Austen's issues of romantic sex and power on screen, specifically in heightening images of masculinity. In Pride and Prejudice, Davies expanded the roles of the men in Austen's novel, such as Mr. Darcy and his friend Mr. Bingley (Crispin Bonham-Carter), and added a series C shots, voice over narration and additional images of them to more thoroughly develop their masculine characters, points of view and male bonding camaraderie resembling a 'bromance.' The BBC mini-series opens with both men riding up on their horses in the handsome greenery and forest landscape to see and discuss renting the Netherfield country estate outside Meryton village in Hertfordshire, England. Davies's adaptation immediat reveals Darcy's lofty aristocratic perspective and unimpressed view of country life as it begins:

\author{
I. A Man of Good Fortune \\ [EXT. COUNTRYSIDE, NETHERFIELD - DAY] \\ [Two men ride on horseback across the country and stop some distance from a large manor to gaze at it.] \\ MR. BINGLEY: It's a fair prospect.
}

MR DARCY: Pretty enough, I grant you.

MR BINGLEY: Oh, it's nothing to Pemberley, I know, but I must settle somewhere. Have I your approval?

MR DARCY: You'll find the society something savage.

MR BINGLEY: Country manners? I think they're charming.

MR DARCY: Then you'd better take it.

MR BINGLEY: Thank you. I shall. I shall close with the attorney directly.

[The two men ride off to the manor. Elizabeth watches them from a hill far away. She begins to walk down the hill, but takes a slow turn to look around her before she goes skipping and running down the dirt road. She continues her walk, picking flowers. She walks past a horse and a colt, and walks down the lane towards Longbourn.]

Davies's six-part adaptation of Austen's Pride and Prejudice novel added a number of atmospheric landscape shots with evocative virile scenes of men riding horses, hunting, fencing, engaging in masculine camaraderie walking with their dogs, and, of course, Darcy's dive into the lake. Moreove Firth is top billed despite it being an Austen adaptation typically centering on women. A woman producer (Sue Birtwistle) convinced a reluctant Firth play Darcy. Davies expanded the role and insisted that he wanted to properly develop the characters to show that the men were actually worthy enough to deserve the fine, intelligent women in Austen's stories. ${ }^{10]}$

Davies's adaptation of Austen's Pride and Prejudice, produced by Sue Birtwistle and directed by Simon Langton, makes atmospheric use of landscapes with many locations filmed throughout the mini-series shot from June to November 1994 in super $16 \mathrm{~mm}$ widescreen (with cinematograr by John Kenway) to enhance its romantic setting and scenery with grassy rolling hills in the English countryside, which also highlight and reflect the emotions of Austen's characters. Ironically, portions of the landscape were cropped and 'panned and scanned' to fit standard television 4:3 aspect ratio when it originally aired on BBC One in September-October 1995. The most evocative incarnation of natural landscape in Pride and Prejudice is that of Darcy's grand estate of Pemberley in Derbyshire, shot on location at Lyme Park in Cheshire, the embodiment of his palatial home with beauti emerald hills, lakes, lush gardens and wooded wilderness which visually personifies Darcy's emotional depth, substance, complexity, and humanize him: as the geographic site where Elizabeth discovers she is attracted to his warm appeal when he unexpectedly lets down his repressed guard of aristocratic arrogance and stuffy snobbish formality to display more earthy human qualities as he takes a casual jump into a pond for a quick swim and emerges disheveled like an ordinary awkward everyday person.

Davies's adaptation of Austen's Pride and Prejudice cleverly employed complex narrative conventions evocative of film noir such as flashbacks and voice over narration of Darcy and Elizabeth reading letters to each other and subjectively reliving past events and conversations psychologically. Davies also developed characters more fully, especially Darcy, and added scenes to convey his masculine point of view. For instance, episode four , Pride and Prejudice opens not from a female point of view with Elizabeth reading a letter, but rather with Darcy shown from his point of view leaving 
Elizabeth in fury and exasperation after his proposal of marriage has been rejected by her and she has criticized his lack of gentlemanly behavior for insulting her and her family. It shows Darcy exiting the building walking outside and returning to his wealthy aunt's estate to brood and think about $t \mathrm{t}$ upsetting encounter up in his room as he resolves to set some things right about her romanticized misconception of his dodgy deadbeat rival Mr. Wickham. Even Elizabeth's voice over narration is played over shots of Firth as Darcy from his point of view remembering her words in his head. As Davies's adaptation begins:

[EXT. ROSINGS PARK - DAY] [Mr Darcy walks down the path toward the house.]

ELIZABETH (V.O.): You are the last man in the world whom I could ever marry. Do you think that any consideration would tempt me? Your arrogance, your conceit, and your selfish distain for the feelings for others. My opinion of you was decided when I heard Mr Wickham's story of your dealings with him.

MR DARCY: Well, at least in that I may defend myself.

Darcy glares pensively out the grey window of his aunt's estate and sits down to write his letter to Elizabeth. Davies's adaptation proceeds:

[INT. ROSINGS PARK, DARCY'S GUEST ROOM - DAY]

[Darcy enters and turns around. He sighs, thinking. He turns around, walks to the desk, sits down, opens a drawer, and pulls out some paper and a pen, dipping it in ink.]

MR DARCY (V.O.): “To Miss Elizabeth Bennet,"

[Darcy dips for more ink and pauses before writing again.]

MR DARCY (V.O.): "Be not alarmed, Madam, on receiving this letter, that it contain any repetition of those sentiments, or renewal of those offers which were, this evening, so disgusting to you."

[Darcy pauses, puts down the pen, and leans back with a sigh.]

MR DARCY (V.O.): "But I must be allowed to defend myself against the charges laid at my door. In particular, those relating to Mr Wickham, which, if true, would, indeed, be grievous; but are wholly without foundation, and which I can only refute by laying before you his connection with my family."

[Darcy stands up and walks to the window, leaning on the frame as he looks out.]

The glass of the window reflects the cold weather and his troubled emotions and distorts his face as the crisscrossing beams of the window pane form bars of entrapment across his grim face. Davies's adaptation of Austen's Pride and Prejudice presents a detailed sequence of flashback image from Darcy's point of view remembering his earlier days with Wickham at home and at the University of Cambridge and Wickham's betrayal of his young sister Georgiana as he writes and narrates his letter. After an extended discussion of the scenes outlining Darcy's flashback, Davies's adaptation continues its development of Darcy's character from his point of view:

[INT. ROSINGS PARK, DARCY'S GUEST ROOM - NIGHT]

[The scene fades to Darcy writing.]

MR DARCY (V.O.): "A secondary motive must have been to revenge himself on me. Had he succeeded, his revenge would have been complete, indeed. This, Madam, is a faithful narrative of all my dealings with Mr Wickham."

[Darcy drops his pen and leans back with a sigh. He rests his head back on the chair, very distressed, before leaning forward with determination, dipping his pen in ink.]

[INT. ROSINGS PARK, DARCY'S GUEST ROOM - MORNING]

[Darcy washes his face in a silver basin. He dries off, now wearing no vest. He sighs and walks over to the desk, snuffs out the shortened candle with his fingers. The letter lies on the desk embossed with his wax seal.]

Later in the episode, the beautiful scenic landscape of green hills, lakes, bridges and woods on his Pemberley estate are shown as Darcy fences an! then rides his horse furiously across his vast wooded lands and pulls his shirt off and dives into the lake to cool off and appease his tormented sexu tension as he is upset over his continued desire for Elizabeth after she spurns him. In a scene written for the series which was not in Austen's novel, Davies's adaptation describes the scene as "Chance Encounter":

[EXT. PEMBERLEY, LAKE - DAY]

[Mr Darcy rides down the road to Pemberley. He slows to a stop and looks at his house through the trees before he rides to a pond a little out of sight and dismounts. Darcy removes his hat and gloves.]

In a behind the scenes interview on the making of the series, Davies explained that Darcy had been riding all day, it was incredibly hot, and it was a brief moment he had to himself before his guests arrived the next day, so he took a moment alone to unwind and cool off in the lake. He had not anticipated the sexual raciness of the scene. ${ }^{[11]}$ Davies's adaptation juxtaposes shots of Elizabeth admiring painted portraits of Darcy at his estate with Darcy's outdoor activities. 
[Elizabeth looks up at the dignified portrait of Darcy.]

[EXT. PEMBERLEY, LAKE - DAY]

[The original Darcy walks closer to the lake, removing his jacket, his cravat, and his vest as his sits down on the grass.]

The sequence crosscuts between these parallel events until they confront each other. Davis' sequence details Darcy's actions by the lake in the woc on his estate:

\section{[EXT. PEMBERLEY, LAKE - DAY]}

[Darcy walks down to the murky green water, pauses to think for a moment and then dives in.]

[EXT. PEMBERLEY, GARDENS - DAY]

[Elizabeth and the Gardiners walk through the gardens alone.]

[EXT. PEMBERLEY, GROUNDS - DAY]

[Darcy walks to the house wearing his boots and soaking wet clothes. He carries his riding stick, hat, and outer clothes while a man servant leads his horse.]

The scene was shot with a long shot of a stuntman double of Darcy diving into the lake followed by closer underwater shots of Firth as Darcy swimming below the surface which was shot in a big tank. Originally, Davies wanted Firth's Darcy to leave the lake and stroll out naked when unexpectedly running into Elizabeth on the grounds of his Pemberley estate, but that idea was censored by the BBC (and it was decided it would be too corny for him to be clad in underwear), so instead Darcy famously emerges in a 'soaking wet' clinging white shirt. In Davies's scene of the climactic moment:

\section{[EXT. PEMBERLEY, GROUNDS - DAY]}

[Elizabeth walks down a slight hill. She hears the rustle of a nearby tree and is shocked to see Darcy emerge. Darcy walks several paces before realizing it's her, and then stops short in surprise.]

ELIZABETH: Mr Darcy!

MR DARCY: Miss Bennet. I...

ELIZABETH (uncomfortable): I did not expect to see you...sir. We understood all the family were from home, or we should never have presumed...

MR DARCY (uncomfortable): Er, I returned a day early. Excuse me; your parents are in good health?

Davies's scene continues to hilarious effect. After Darcy awkwardly excuses himself and Elizabeth rushes to leave, he hurriedly returns to make a better impression:

\section{[EXT. PEMBERLEY - DAY]}

[Darcy opens the door and rushes down the stairs, completely re-dressed. He buttons up the front of his jacket as he looks around for Elizabeth and the Gardiners. Darcy steps out of the courtyard to where their carriage awaits just as Elizabeth rushes towards it.]

MR DARCY: Miss Bennet. [Elizabeth turns around, and Darcy continues walking to her.]

MR DARCY: Please allow me to apologize for not receiving you properly just now. You are not leaving? ${ }^{[12]}$

This scene visualizing Davies's adaptation is wonderfully shot against the imposing grey stone buildings on Darcy's Pemberley estate as he rapidly emerges from an impressive arched tunnel still quickly fastening his clothes. He then graciously invites then to stay and takes them for a walk in the woods to show her uncle the good fishing in the lake. As Darcy later hands Elizabeth into the carriage, thanking them and wishing they will return sc as he stands adjusting his jacket, his farewell in Davies's adaptation of Austen again centers on Darcy and his image:

[Darcy bows and steps back and watches the carriage drive away. Elizabeth turns back to look at Darcy as he shrinks into the distance.] ${ }^{[13]}$

Not only did Miss Elizabeth 'Lizzy' Bennet change her mind about him, but Firth's image as Darcy created quite a sensation with spectators. Davies insisted he initially meant for the scene of their encounter in his wet garbed attire to simply be embarrassing for the arrogant character of Darcy to $b$ seen not properly dressed; however, it created a legendary stir with viewers who recognized its suggestive sexuality, as well, and Firth soared to stardom. The encounter between Elizabeth and Darcy in Davies's adaptation of Austen's Pride and Prejudice has since been acclaimed as one of th great scenes in British television history. ${ }^{[14]}$

In 2005, Davies announced that he would adapt another Austen classic, Sense and Sensibility, for the BBC, following the success of his Pride and Prejudice-inspired Bridget Jones's Diary and Bridget Jones: The Edge of Reason, and a decade after his adaptation of Austen's Pride and Prejudice. [15] Austen's Sense and Sensibility, adapted by Davies in 2007 and produced by the BBC (with American PBS station, WBGH in Boston), was described as "a voyage of burgeoning sexual and romantic discovery" when it aired as a BBC television mini-series in January 2008. ${ }^{16]}$ 
Shot entirely on location in England, Davies's 2008 BBC version of Austen's Sense and Sensibility began two months of filming from April-June 200i on locations in Devon, Berkshire, Surrey, and Buckinghamshire. Natural outdoor locations visually transformed Davies's romantic adaptation of Austen's Sense and Sensibility to convey evocative landscapes and atmospheric settings revealing the emotions of the characters on screen, such : the rustic Barton Cottage home of the Dashwood sisters in Austen's novel, shot on location at Blackpool Mill cottage surrounded by harsh, beautifu North Devon sea cliffs. Producer Anne Pivcevic and director John Alexander recalled how they initially planned to capture the sunny green hills and landscapes of Davies's rendering of Austen's romantic novel Sense and Sensibility (as in many scenes of the 1995 BBC version of Pride and Prejudii with women running in the grass with bonnets and white dresses). However, they suddenly encountered bad weather shooting in Devon in May and had to film in torrential rain as monsoon season began. ${ }^{[17]}$ Cast and crew were soaked during the arduous extensive outdoor location filming (shot $b$ cinematographer Sean Bobbitt).

Such location filming production conditions for Sense and Sensibility transformed the look and feel of Davies's cinematic adaptation of Austen's romance narrative and produced haunting, mesmerizing landscapes illustrating the agonized romantic feelings, sexual tension, and gender distress the story's characters. The resulting BBC production of Davies's version of Austen's Sense and Sensibility also drew on the legendary scene from Davies's earlier 1995 BBC version of Austen's Pride and Prejudice. As Davies turned up the sexual heat in his adaptation of Austen's Sense and Sensibility, and developed masculine characters by added manly scenes of hunting, horseback riding, a fencing sword duel, and a scene where the story's tormented antihero, Edward (Dan Stevens) chops wood with an ax outdoors to release his sexual frustration, Pivcevic and Alexander claimec was originally to be shot in the sunshine. Yet, after filming Sense and Sensibility in monsoon conditions in Devon in May, the ax-chopping scene in tl pouring rain became a scene reminiscent of Pride and Prejudice as Davies reimagined the troubled Edward violently swinging his ax in a soaking w $\epsilon$ white shirt (like Firth's Darcy). (Actor Stevens suffered tonsillitis throughout most of the shooting of Sense and Sensibility. ${ }^{[18]}$

Moreover, the turbulent landscape and bad weather while filming Sense and Sensibility visually captured Edward's moody emotions and that of the heartbroken heroines, Elinor Dashwood (Hattie Morahan) and her sister Marianne (Charity Wakefield). In fact, rain, rocks and raging surf are recurren visual motifs throughout Sense and Sensibility reflecting its themes of romantic loss and longing. Producer Pivcevic, director Alexander, art director/production designer James Merifield and costume designer Michele Clapton admitted the cast and crew of Sense and Sensibility were thrill with the film's transformed 'raw' 'earthy' tone, with wind blown rainy shots which although 'agonizing to film,' added greater realism and authenticit) as is evident in its remarkable, evocative brooding landscapes. Pivcevic explained that many scenes that were to be shot in the sun on grass were suddenly shifted to caves and the rocky coastline for an impressive atmospheric effect. ${ }^{[19]}$ The most powerful image in Sense and Sensibility is a striking shot of Elinor in silhouette in a cave looking out from the dark to the jagged, obliquely slanted grey rocks of the coastline, a harsh landscap $\epsilon$ that visually projects her bleak emotional devastation at finding out that her love Edward is secretly engaged to another and having to suffer in silenc without being able to tell anyone. Thunder rumbles in the distance as she broods in the dark and agonizingly keeps the secret from her sister. Anoth impressive evocative landscape is shown when her sister Marianne falls down the cliff along the hilly Devon coastline in the rain, and later walks soaked in a torrential downpour after she is heartbroken, betrayed and nearly dies, before she is rescued by horse riding hero, Colonel Brandon (Da' Morrissey).

By the end of May 2007, after the crew began filming rainy landscapes in Devon, Claire Hill wrote in Cardiff's Western Mail that "Davies does anothe novel sexing up and it's Jane Austen tweaked again." In fact, despite the unpredictable weather affecting filming production conditions, she wrote $\circ$ Sense and Sensibility evoking Pride and Prejudice and announced in racy tagline publicity fashion, "Screenwriter Andrew Davies has revealed how $\mathrm{r}$ has written a new 'wet shirt scene' to rival the one he penned for Colin Firth's iconic Pride and Prejudice moment more than 10 years ago. Firth shot fame, and sent many female viewers' hearts racing, when he played Mr. Darcy emerging dripping wet from a lake during Davies's famous TV adaptation of Jane Austen's novel." She explained, "Now the Cardiff-born screenwriter has told of how he has sexed-up and 'butched-up' Austen's Sense and Sensibility with a rainy wood-chopping scene. He has also added a controversial scene involving the on-screen seduction of a 15-year-o girl."."20]

Davies opened the new adaptation of Austen's Sense and Sensibility with a shocking film noir styled scene of the film's scoundrel John Willoughby (Dominic Cooper) seducing an innocent young girl with the heavy breathing and false promises of a sexual predator in the flickering orange flames a shadows of fire light. Davies boldly proclaimed, "I think Jane [Austen] could have done with working through another draft of Sense and Sensibility, 1 be frank. She should have managed to make us feel that Edward was worthy of Elinor and even though she shows Colonel Brandon is worthy of Marianne, Austen never explains how Marianne goes from desperately in love with Willoughby to broken-hearted to be in love with Brandon. The $\mathrm{m} \epsilon$ needed butching up and you needed to see more of them." He added, "We worked very hard on those guys...Brandon does a lot of fast-riding and rescuing people and I have given Edward a wood-chopping scene. It fits because he is frustrated and tense about his secret engagement so he see these logs, starts chopping, and would you believe it, the rain starts." [21] In Davies's adaptation, Brandon rides horses, lets independent Marianne roam in his library and music room to discover books, musical scores, and play the piano forte, then lets her watch him train a falcon to fly and land his arm until the freedom loving adventurous romantic heroine finally falls in love with him after recovering and getting over her heartbreak from scoundrel Willoughby. Willoughby is portrayed as much less sympathetic in Davies's version of the story.

Davies admitted he was initially reluctant about Morahan's casting as the lead Austen heroine Elinor, but later grew to love her performance. ${ }^{[22]}$ Davi reveled in bringing elements of Austen's story to the screen in his adaptation of Sense and Sensibility. He explained Austen "puts storylines and subplots in the novels that sometimes people don't notice" which was important to highlight, including a duel and seduction of a young girl. Davies recognized "there was a whole interesting subplot that is left out of the [1995] film altogether in order to preserve the sex appeal of Willoughby as lo: as possible." Davies insisted, "while competing with people's recollection of the Oscar-winning film version was difficult," they were able to 'eclipse' Davies felt Sense and Sensibility, "one of Austen's best-loved novels...needed some tweaking-not least to differentiate it from a recent box-office 
adaptation of the same novel."[23] Davies compared his adaptation to the previous 1995 version of Austen's Sense and Sensibility starring/scripted k Emma Thompson, costarring Hugh Grant, Kate Winslet and Alan Rickman. "It was a very good film, beautifully directed by Ang Lee...So obviously th aim is to try and make people forget about" it. "Our lovely version is going to clearly obliterate...memories of the film."[24]

In adapting the BBC romantic mini-series from Austen's novel, Davies developed supporting and masculine characters, backgrounds, and also highlighted the story's sexual tension and gender distress. In fleshing out characters in the ensemble, Davies strengthened several masculine roles such as romantic leads Edward and Brandon with additional scenes, and also developed comic supporting characters such as Miss Lucy Steele's (Anna Madeley) sister Anne (Daisy Haggard). Many comedic portrait shots are filmed in fine deadpan fashion with distorted wide angle lenses to enhance the comedy's absurd humor, as with images of the Dashwood sisters' older stepbrother, John (Mark Gatiss) [and his chubby silent son], wit ridiculous bright orange hair, his selfish wife Fanny (Claire Skinner) with uptight curls plastered to her forehead, Mrs. Dashwood's hilarious cousin, $\mathrm{Si}$ John Middleton (Mark Williams), and his matchmaker mother-in-law Mrs. Jennings (Linda Bassett).

In addition, Davies explained that his intension was also to add some disturbing, provocative sexual details to the romance. He described wanting " do justice" to "quite interesting and steamy stuff like a lot of underage sex that goes on and is just talked about" in Austen's novel. "I want to put it c the screen." [25] Davies observed, "In the novel round about the time that Elinor, Marianne and her mother are being shunted out of the family home, Willoughby spirits a 15-year-old girl, who happens to be Colonel Brandon's daughter, away from school, takes her to a cottage and, I am afraid, give her a good seeing to. I thought, 'Should we not see this on screen?' These are the thoughts that occur to a man as warped as I am." [26] Davies addt raw emotion and realism to his adaptation of Austen's Sense and Sensibility and made its heroines, sisters Elinor (19) and Marianne (17), younger an more 'vulnerable' than in the earlier film. ${ }^{[27]}$

The extraordinary landscapes enhanced their realistic romantic portrayals. In particular, Davies's rendering of Austen's Sense and Sensibility and Wakefield's vibrant performance breathes life into Marianne. Marianne, perceptive and keenly aware of the world around her, provides insightful gender critique, despite grappling with her own heartbreak and psychological demons. After learning of Willoughby's callous abandonment of the young girl (and her baby) he seduced to marry a rich heiress, Marianne painfully whispers to Elinor under the sheets of their bed, "What strange creatures men are. What do they want from us? Perhaps they see us not as people, but as play things." [28] The visual landscape and color scheme shifts dramatically from a warm amber glow to a harsh, cold periwinkle blue-grey signifying her emotional pain and torment as she runs selfdestructively into the turbulent landscape of a violent storm in a torrential downpour under thundering skies. Similarly, the dangerous violence of the duel between Marianne's romantic rivals Brandon and Willoughby is shot in steely cold blue-grey tones juxtaposed with icy blue shots of her tearfull writing a frantic letter to Willoughby.

Stunning landscapes in Sense and Sensibility cinematically projected their emotional romantic torment on screen, even in silence with no dialogue. The magnificent tableau shots filmed on actual locations and tumultuous wind blown weather created a harsh alternate world of brooding textures a an unvarnished, atmospheric milieu for Davies's adaptation of Austen's Sense and Sensibility, with spectacular dramatic landscapes of the rocky clif with waves crashing violently against jagged boulders on the coastline and lush emerald green hills of Devon, which was reminiscent of landscapes a Gothic romance. For instance, a haunting image is shown after innocent, romantic Marianne is betrayed and spurned by Willoughby, as she hover miserably cowering against the bank of a steep hill, somberly hidden from everyone in the cold rain, as a waterfall rushes down a grassy creek behir her. Such evocative Gothic landscapes and location shots in Davies's Sense and Sensibility visually and thematically eclipsed earlier work to evoke : darker existential 'noir' variation on Davies's adaptation of Austen's Pride and Prejudice, as well as earlier screen versions of Sense and Sensibility.

The moody tenor of Davies's Sense and Sensibility was cinematically powerful in visually rendering the troubled emotions of the story's tormented antiheroes and heroines, as well as adapting the wit and romance of Austen's novel. The wonderful depth, brooding tone and complex textures of Davies's version of Austen's Sense and Sensibility, with its breathtaking Gothic tableau and striking landscapes, reflected the inner turmoil of its characters and smoldering repressed passions, as in Firth's incarnation of Darcy in Davies's adaptation of Austen's Pride and Prejudice. Ultimately, I a force of nature, as an unexpected result of the turbulent weather, the bleak cinematic landscapes and earthy 'authentic' realism in its mise-en-sce| brought the sexual tension and gender distress in Sense and Sensibility vividly to life with a raw intensity that was pensive and unpredictable, reflect in its stunning cinematography and stark iconography rivaling Pride and Prejudice in conveying the searing hopes, dreams, loves, frustrations, and emotional heartaches of Davies's incarnation of Austen's romantic characters on screen. As the Dashwood heroines' young sister Margaret ponders the social and economic constraints of women in a man's world in Davies's adaptation of Austen's Sense and Sensibility, Elinor and Marianne are eventually 'saved' by marrying the men they love (in a double wedding, as in Pride and Prejudice) by the end of the series, and one wonders what th future holds for Margaret further down the road, both in terms of romantic love (or independence) and sexual identity.

\section{Notes}

1. Gilles Deleuze, Negotiations, 1972-1990, trans. Martin Joughin, New York: Columbia University Press, 1997.

2. Jane Austen's Pride and Prejudice inspired a modern incarnation in the Bridget Jones motion picture 'trilogy' franchise for Studio Canal/Miramax/Working Title/Universal: Sharon Maguire's Bridget Jones's Diary (2001, adapting Helen Fielding's 1996 novel drawn from her 1995 Independent column based on Davies's 1995 adaptation of Austen's Pride and Prejudice), Beeban Kidron's sequel Bridget Jones: The Edge of Reason (2004), followed by the less impressive Bridget Jones's Baby (2016), which was adapted without Davies and without star Hug Grant.

3. For instance, Deborah Cartmell considered Austen's Pride and Prejudice to be the quintessential film/television literary adaptation text. Sue Parrill acknowledges the appeal of adapting Austen's stories for film and television in relation to gender and setting, although characterizing Austen's work as 'simple love stories' with well-written characters, not expensive to adapt (especially since they are in the public domain and 
screen companies don't need to pay the author), they require "no expensive special effects, no exotic locations, and only a small cast," and Austen's gender critique resonates with a 'female audience' and thus appeals to women. See Deborah Cartmell, Jane Austen's Pride and Prejudice (London: Methuen Drama, 2010). Sue Parrill, Jane Austen on Film and Television: A Critical Study of the Adaptations (Jefferson, Nor Carolina: McFarland, 2002), 3-5. For further reading, see Gina MacDonald and Andrew MacDonald, Jane Austen on Screen (Cambridge: Cambridge University Press, 2003), Linda Troost and Sayre N. Greenfield, eds., Jane Austen in Hollywood (Lexington: University Press of Kentucky, 2001), John Wiltshire, Recreating Jane Austen (Cambridge University Press, 2001), and Julianne Pidduck, "Of windows and countr walks: frames of space and movement in 1990s Austen adaptations," Screen, 39.4, (1998), 381-400.

4. The success of Davies's 1995 BBC adaptation of Austen's Pride and Prejudice and the resulting revival of Austen's popularity in feature films produced illustrates the resonance of Davies's interpretation of Austen's work as romantic screen narratives. In fact, Davies's reimagining of Austen heightens the significance and importance of gender polemics and constraints, masculinity, and location settings in Austen's romantic gendered landscapes. After the successful 1940 Hollywood film version of Pride and Prejudice there seemed to be a dearth of interest in adapting Austen on film. Indeed, despite BBC television versions of the novels, there were surprisingly no British or American feature film adaptations of Austen until 1995, when there was suddenly a flurry of Austen film romance adaptations, including Persuasion, Pride and Prejudice, Sense and Sensibility, Clueless and two versions of Emma in 1995-1996, and Davies's acclaimed BBC television adaptation of Austen's Pride and Prejudice earned 1,620,225 pounds and sold 150,000 copies of the video and of Austen's book.

5. For example, Julianne Pidduck observes how romantic heroines in Davies's version of Austen's Pride and Prejudice (like Sense and Sensibility gaze upon scenic landscapes from windows "as a picture...drawn towards the inviting outdoors, where...picturesque grounds come into shar relief as the Dashwood daughters' rightful inheritance denied them by patriarchal law." As she explains, in Pride and Prejudice, after rejecting romantic hero Darcy's marriage proposal, Austen heroine Elizabeth "finds herself gazing out of an upper window" of his Pemberley estate. Sh adds, "In a typically ironic Austen moment (heightened by Andrew Davies'ss knowing screenplay) she muses to herself, 'Of all this I might hav been mistress." Pidduck," Of windows and country walks," 383.

6. In The Dangerous Lover, Deborah Lutz considers Austen's romance stories such as Sense and Sensibility and Pride and Prejudice and their tormented (anti)heroes in relation to darker menacing 'homme fatales' in female Gothic romances and their troubled gender and sexual relatio as in Jane Eyre and Rebecca. Deborah Lutz, The Dangerous Lover, (Columbus: Ohio State University Press, 2006), 43-44.

7. Also, women directors Sharon Maguire and Beeban Kidron, adapting Davies's Austen in a contemporary context in Bridget Jones films, and $\subseteq$ Wyatt editing Northanger Abbey.

8. Andrew Davies, adaptation of Jane Austen's Sense and Sensibility, BBC/WBGH, 2008.

9. Anne Pivcevic behind the scenes interview on making Sense and Sensibility, BBC/WBGH, 2008.

10. Even in Davies's clever modern adaptations of Austen's Pride and Prejudice in the Bridget Jones films, his male characters are strong, witty a| keenly written with sexual tension rivalry resembling a 'bromance' between them along with the story's heroine, which is essential to their effective romantic comedy narratives. Davies is also known for developing strong, memorable masculine characters in many of his other (non Austen) screen adaptations, such as Daniel Deronda (2002), Mr. Selfridge (2013), and his acclaimed neo-noir versions of House of Cards (1991 2013).

11. Andrew Davies behind the scenes interview on making Pride and Prejudice, BBC, 1995.

12. Andrew Davies, adaptation of Jane Austen's Pride and Prejudice, BBC, 1995.

13. Davies, adaptation of Austen's Pride and Prejudice, BBC, 1995.

14. In fact, Davies's adaptation of Austen's Pride and Prejudice was such a success that Davies updated his adaptation of it for Sharon Maguire's 2001 film Bridget Jones's Diary (adapting Helen Fielding's 1996 novel, itself a modern day romantic comedy version originally inspired by Davies's 1995 adaptation of Austen's Pride and Prejudice) and Beeban Kidron's 2004 sequel film Bridget Jones: The Edge of Reason (based c Fielding's 1999 sequel novel). Andrew Davies behind the scenes interview on making Pride and Prejudice, BBC, 1995.

15. It is worth noting that the beautiful romantic cinematic landscape of Thailand in Bridget Jones: The Edge of Reason was entirely destroyed by the 2004 Tsunami disaster shortly after the cast and crew shot on location there, dramatically transforming the landscape, captured on film, which no longer existed. As a testament to the pervasive influence of Davies's 1995 adaptation of Austen's Pride and Prejudice, Fielding admitted Firth's Darcy inspired her to update and adapt Austen's Pride and Prejudice into her novel (and column) Bridget Jones's Diary, and tl Bridget Jones films starred Firth as Darcy opposite Hugh Grant (the 1995 romantic male lead in Sense and Sensibility) as Daniel Cleaver, and these strong, memorable masculine romantic comedy antiheroes and their fierce rivalry and sexual tension resembling a 'bromance' are intrin to the brilliant chemistry, conflict and success of Davies's quirky Austen adaptations starring Renee Zellweger as Bridget Jones. Both Bridget Jones's Diary and Bridget Jones: The Edge of Reason open with striking atmospheric landscapes: a snowy winter scene in Snowshill, Gloucestershire (and, later, Hertfordshire) like a Christmas card in Bridget Jones's Diary and a stunning aerial landscape of the heroine skydivi in Bridget Jones: The Edge of Reason which later shifts to spectacular travelogue images of the beaches, oceans and island cliffs of Thailand These cinematic spaces are juxtaposed with the cramped, claustrophobic, imposing confines of the Thai prison Bridget is thrown into until he estranged jealous former lover Darcy gets her out. Bridget Jones's Diary includes sweeping aerial landscapes of the beautiful English countryside in Stoke Park, Buckinghamshire with wonderful shots of romantic couples paddling boats, reading poetry and, like Darcy in Pride and Prejudice, splashing into the lake. Bridget Jones's Diary captures the pulsating urban landscape of London as Bridget crosses Tower Brid and, despite its hilarious comedy, even a nocturnal film noir milieu as romantic male rivals Darcy (Firth) and Daniel Cleaver (Hugh Grant) fight and crash through a shattering window onto glistening wet streets surrounded by broken glass among the shadows cast by the streetlights. II the Bridget Jones: The Edge of Reason sequel, Darcy and Cleaver engage in a wild brawl rife with 'bromantic' sexual tension as they wrestle soaking wet while splashing in a water fountain. Moreover, years after Davies's adaptation of Austen's Pride and Prejudice, by 2007 Davies als adapted Austen's Gothic romance parody Northanger Abbey for ITV (directed by Jon Jones, produced by Keith Thompson, edited by Sue Wyatt), filled with shadowy Gothic noir imagery and a haunted mansion resembling eerie troubled great houses such as Thornfield in Charlott Brontë's 1847 British Gothic novel Jane Eyre, Emily Brontë's 1847 Wuthering Heights, Manderley in Daphne du Maurier's 1938 Gothic novel 
Rebecca, and the creepy castle in Mary Shelley's Frankenstein (1818). Yet, while Davies's 2007 ITV adaptation of Austen's first completed nov Northanger Abbey (not published until after her death in 1817) featured shadowy noir styled Gothic visuals and a sinister looking great house that seemed haunted by death, the story nonetheless remained a comic parody of Gothic romance with stylized surreal fantasy dreams and imaginings which actually discuss how unrealistic Gothic novels are and how the naïve young heroine Catherine (Felicity Jones) reads too ma of them.

16. BBC publicity for BBC/WBGH series Sense and Sensibility, 2008.

17. Anne Pivcevic and John Alexander behind the scenes interview on making Sense and Sensibility, BBC/WBGH, 2008.

18. Anne Pivcevic, John Alexander and Dan Stevens behind the scenes interview on making Sense and Sensibility, BBC/WBGH, 2008. (Stevens' tormented incarnation of Edward in Sense and Sensibility anticipates his later moody character Matthew in Downton Abbey.)

19. Pivcevic, Alexander, James Merifield and Michele Clapton behind the scenes interview on making Sense and Sensibility, BBC/WBGH, 2008.

20. Claire Hill, "Davies does a another novel sexing up and it's Jane Austen tweaked again," Western Mail (Cardiff, Wales), May $28,2007$.

21. Andrew Davies quoted in Claire Hill, "Davies does a another novel sexing up and it's Jane Austen tweaked again," Western Mail (Cardiff, Wale May 28, 2007.

22. Davies in Peter Chapman, "Andrew Davies," The Independent, December 30, 2007.

23. Hill, "Davies does a another novel," Western Mail, May 28, 2007.

24. Davies quoted in Hill, "Davies does a another novel," Western Mail, May 28, 2007.

25. Andrew Davies quoted in Claire Hill and Paul Carey, "You have to get sex into the spine of a story," Western Mail, May $29,2006$.

26. Davies quoted in Hill, "Davies does a another novel," Western Mail, May 28, 2007.

27. Andrew Davies quoted in Andrew Pettie, "Sense and Sensibility: Sex and sensuality," The Daily Telegraph, December $29,2007$.

28. Davies, adaptation of Austen's Sense and Sensibility, BBC/WBGH, 2008.

\section{Cite this Essay}

https://doi.org/10.20415/rhiz/033.e01

RHIZOMES ISSN 1555-9998 $\star 230$ East Hall Bowling Green State University Bowling Green, OH 43403

Editors: Ellen Berry and Carol Siegel. Reviews editor: Craig J. Saper. Technical editor: Helen J Burgess 